Houwink, A. L., and P. A. Roelofsen. 1954. Fibrillar architecture of growing plant cell walls. Acta Bot. Neerl. 3: 385-395.

Küster, E. 1956. Die Pflanzenzelle. Gustav Fischer Verlag, Jena.

Ordin, L., R. Cleland, and J. Bonner. 1955. Influence of auxin on cell-wall metabolism. Proc. Nat. Acad. Sci. (U. S.) 41 : 1023-1029.

- - - AND - 1957. Methyl esterification of cell wall constituents under the influence of auxin. Plant Physiol. 32: 216-220.

Preston, R. D. 1952. Biological units of cellulose structure. Symposia Soc. Exp. Biol. 6: 348-357.

, E. Nicolai, and B. Kuyper. 1953. Electron micro. scopic investigations of the walls of green algae II. The cytoplasm-wall relationship in freeze-dried Valonia macrophysa. Jour. Exper. Bot. 4: 40-43.

——, AND A. B. Wardrop. 1949. The submicroscopic organization of the wall of conifer cambium. Biochim. et Biophys. Acta 3: 549-559.

Steward, F. C., and K. Mühlethaler. 1953. The structure and development of the cell-wall in the Valoniaceae as revealed by the electron microscope. Ann. Bot. N. S. 17: 295-316.

TAYLOR, J. H. 1956. Autoradiography at the cellular level. Physical techniques in biological research. Vol. 3. Academic Press, New York.

Wardrop, A. B. 1955. The mechanism of surface growth in parenchyma of Avena coleoptiles. Austral. Jour. Bot. 3: 137-148.

WILson, K. 1951. Observations on the structure of the cell walls of Valonia ventricosa and of Dictyosphaeria favulosa. Ann. Bot. N. S. 15: 279-288.

1957. Extension growth in primary cell walls with special reference to Elodea canadensis. Ann. Bot. N. S. 21: 1-11.

\title{
DEVELOPMENT AND CYTOLOGY OF THE EVANESCENT PROSORI OF SYNCHYTRIUM BROWNII KARLING ${ }^{1}$
}

\author{
B. T. Lingappa
}

Synchytrium Brownil is a long-cycled species which Cook (1945) identified as $S$. fulgens Schroet. on Oenothera laciniata Hill. in Louisiana. According to the original description by Schroeter (1873) and later studies by Kusano $(1930 \mathrm{a}, \mathrm{b})$, the content of the initial cell of $S$. fulgens cleaves and develops into a sorus of sporangia at maturity. On the other hand, Karling (1954a) found that the content of the initial cell of $S$. brownii grows out to form a superficial sorus of sporangia within the infected host cell, a type of development different from that described for $S$. fulgens. On this ground Karling (1954a) diagnosed $S$. brownii as a new species. Subsequently, Karling (1956) found that the $S$. brownii type of development occurs in all but two collections of specimens which are labelled $S$. fulgens in various herbaria in Europe, Japan and the United States. This discovery suggests that Schroeter and Kusano might have overlooked the presence of an evanescent prosorus in $S$. fulgens and that $S$. brownii and $S$. fulgens may be identical. The solution of this problem is complicated by the fact that type specimens were not designated at the time Schroeter described S. fulgens. Therefore, until extensive studies are made and the type of

${ }^{1}$ Received for publication August 3, 1957.

The present paper is a portion of a thesis submitted to the faculty of the Purdue University in partial fulfillment for the degree of Doctor of Philosophy. The author is grateful to Dr. J. S. Karling for guidance and helpful criticism throughout the investigation. He is also thankful to Dr. G. B. Cummins for stimulating discussions and to Dr. J. R. Singleton for translating Mme. Heim's paper into English and checking the cytological preparations. Grateful acknowledgment is made of the financial support by a grant from the National Science Foundation as well as from a David E. Ross Fellowship.
S. fulgens is designated it is difficult to solve this problem. In the meantime, a thorough study of $S$. brownii is essential for comparison with Kusano's intensive study of $S$. fulgens. The present study, accordingly, concerns the development and cytology of the evanescent prosorus, sorus and sporogenesis in $S$. brownii.

Material and METHODS.--Synchytrium brownii was collected on Oenothera laciniata at Baton Rouge, Louisiana and transferred to $O$. biennis which is more satisfactory for inoculation and maintenance of the fungus throughout the year. Seeds of a local wild variety of $O$. biennis were collected, sown periodically in the nursery beds, and the plants potted after they had attained the rosette stage. Such plants were inoculated with ripe sporangia and zoospores in the greenhouse, at desired intervals, as described by Karling (1954h, c; 1955a, d) for other Synchytrium species. Infection and early development of the fungus were studied in young living leaves as well as in strips of epidermis taken at successive intervals of time after inoculation. At the same time, infected leaves with different developmental stages were fixed in Cleland's modified Bouin's solution, formalinaceto-alcohol, Randolph's modified Navashin's fluid (Craf.) and other killing solutions. The materials were dehydrated through n-butanol-ethanol series,

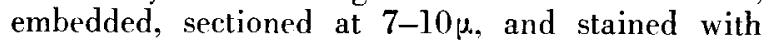
safranin-fast green, Newton's crystal violet and Flemming's triple stain. The following description of cytology and development is based on materials obtained from infected plants which were grown in the greenhouses during 1954-57. Inside the greenhouses the temperature during the daytime 
was frequently above $30^{\circ} \mathrm{C}$. and diurnal fluctuations were $14-30^{\circ} \mathrm{C}$. during May to September. For the rest of the year the temperature was thermostatically controlled at approximately $27^{\circ} \mathrm{C}$.

INFECTION.--When placed in fresh charcoal treated water at $20-27^{\circ} \mathrm{C}$., the ripe sporangia form planospores within $30 \mathrm{~min}$. The planospores swim about actively for several $\mathrm{hr}$. and ultimately settle down. They are oval or obpyriform when active, spherical to subspherical when sedentary and measure $4-5 \mu$ in diameter. About $3 \mathrm{hr}$. after they become sedentary, they begin to take up water and swell to $15 \mu$ or more in diam. and disintegrate on microscope slides. On a suitable host surface, however, the sedentary planospores become firmly attached (fig. 1), and this becomes evident when attempts are made to dislodge them by moving or lifting the cover glass in water mounts. A narrow protoplasmic outgrowth develops from the attached spore at the point of contact with the host surface. The tube pierces the cuticle and cell wall and enters the lumen of the epidermal cell. Then the content of the spore gradually flows into the host cell, and a deformed, hyaline spore case, $1.5 \times 3 \mu$, is left behind on the host surface. The refractive globules of the planospores adhere to the inside of the discarded spore cases (fig. 2). The globules coalesce, spread irregularly and persist for some time after the spore cases disintegrate. Similar observations were also made in S. taraxaci (de Bary and Woronin, 1863), S. fulgens (Kusano, 1930a) and in S. australe (Karling, 1955a), whereas, in S. endobioticum Curtis (1921) reported that entire zoospores as well as zygotes entered the host cells. Inside the host cell, the content of the zoospore appears as a dense mass quite distinct from the surrounding host cytoplasm. (fig. 2). Under very moist conditions and at $20^{\circ} \mathrm{C}$. about $2 \mathrm{hr}$, are needed for formation of abundant planospores from sporangia, 3-5 hr. for cessation of activity of a large number of planospores, about $2 \mathrm{hr}$. for the sedentary spores to become attached to the host surface and 1-3 hr. for the entry of their contents into the host cells, or a total of 8-12 hr. for infection. However, this time schedule varies with experimental conditions, especially temperature and humidity. Abundant infection occurs within 24 hr. after ripe sporangia are inoculated and maintained under favourable greenhouse conditions. Active planospores which were retained for $72 \mathrm{hr}$. at $5^{\circ} \mathrm{C}$. are capable of infecting the host. However, those kept at $27^{\circ} \mathrm{C}$. for nearly $6 \mathrm{hr}$. become sedentary and are incapable of causing infection. Zygotes frequently occur amidst the sedentary planospores and are distinguishable by their characteristic appearance (fig. 1). Large numbers of planospores and zygotges settle on the epidermal cells of the host, and several of them may infect a single host cell. Infection of tender epidermal hairs rarely occurs.
Development of the evanescent prosorus.-The mature initial cell of $S$. brownii functions as a prosorus, and inasmuch as it persists for a relatively short time after maturity it is called the evanescent prosorus. Its development in relation to the host nucleus and cytoplasm is shown in fig. 3-16. These stages are essentially similar to those of S. endobioticum, S. ranunculi, S. australe among other species as described by Curtis (1921) and Karling (1955a, b, c, e). Therefore, the present discussion will be confined to notable differences. One day after entry into the host cells, the thalli are located at the base of the host cells close to the host nucleus (fig. 3). The thalli grow rapidly, and after the third day their nucleoli gradually become vacuolate and chromatic granules appear in the nucleus. The chromatic granules are abundant on the filaments of the crown or lunate body which lies to one side of the nucleolus (fig. 5-11). Curtis (1921) also found in S. endobioticum a direct correlation between the abundance of chromatic granules in the nuclear cavity and the vacuoles in the nucleolus. According to her, the number and size of the vacuoles in the nucleoli correspond to those of the globular buds extruding from the nucleoli. However, in S. brownii it appears as if the globular chromatic material has oozed out from discrete areas in the nucleoli and left the vacuoles behind (fig. 9). In six-day-old thalli chromatic granules occur prominently on the delicate strands which traverse the nuclear cavity from the undulating margin of the crown to the nuclear membrane. They accumulate on the inside of the latter along with one or more heterochromatic globules (fig. 9, 10). In S. fulgens Kusano (1930a) reported that the chromatic granules are transported from the crown to the nuclear membrane and then passed into the cytoplasm. Similar but periodic extrusions of chromatic granules into the cytoplasm were reported in S. endobioticum by Curtis (1921) and by Köhler (1932). Regardless of whether or not the nuclear extrusion occurs in the same manner described by these workers, in $S$. brownii numerous coarse deep-staining granules accumulate in the cytoplasm from the fifth-day stage onwards. Extrusion of these granules appears to reach a climax in the six-day-old thalli and ceases in the eightday-old thalli. The chromatic granules increase in size as they are dispersed in the cytoplasm. Enlargement is accompanied by increased vacuolation and decreased stainability of these granules. Concomitant with these developments, the granules decrease in the nuclear cavity and the chromatic filaments making up the crown thicken, untangle and occupy most of the nuclear vacuole (fig. 11, 12).

Formation of sorus and sporangia.-In the majority of thalli vegetative growth is apparently completed in 9 days. There are, however, large numbers of evanescent prosori of the same age 

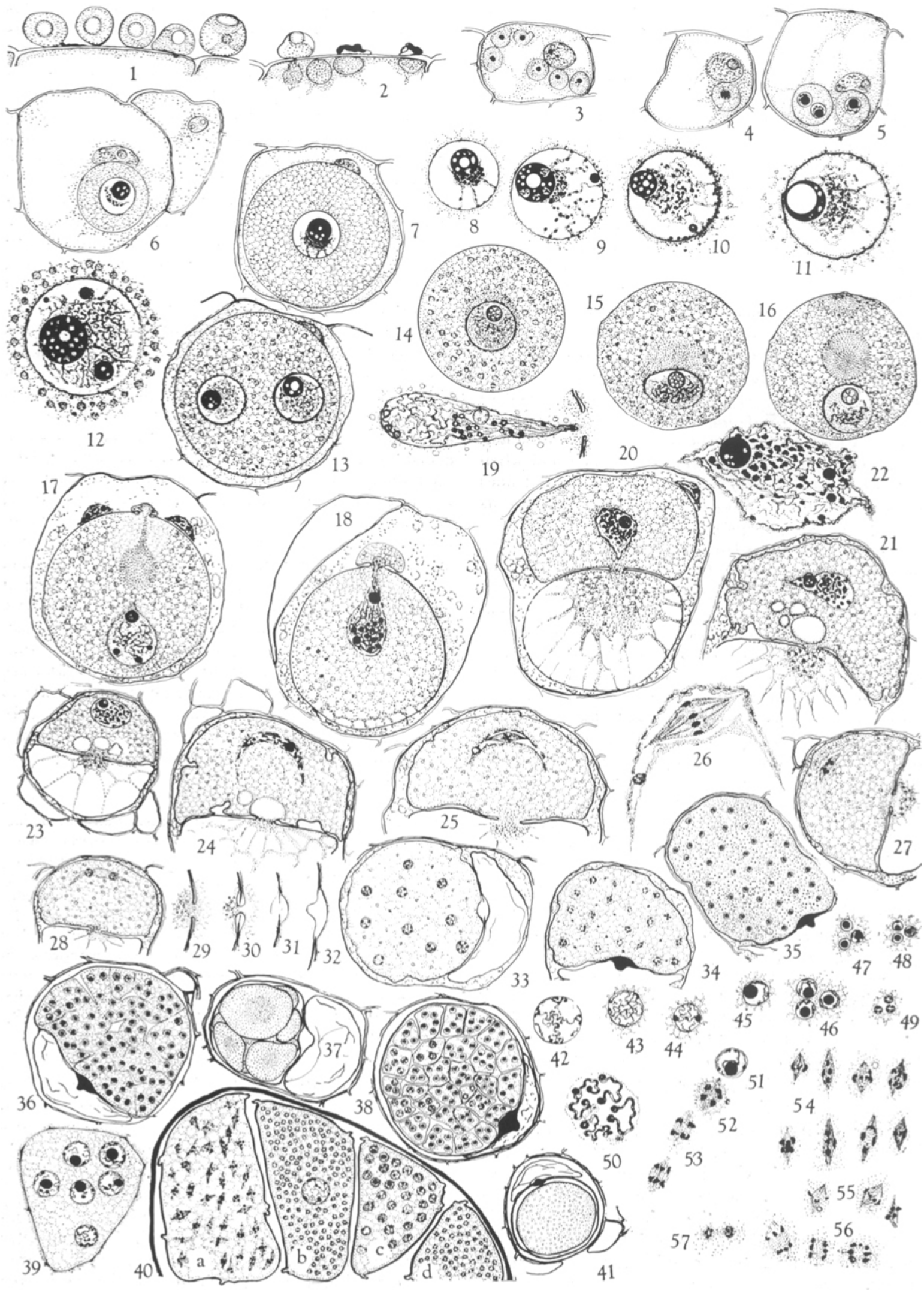
which do not mature until 3-5 days later. The mature evanescent prosori are usually spherical or subspherical (fig. 14-16) and measure 50-145 $\mu$ in greatest diameter. They do not fill the host cell completely so that a space, approximately $20 \mu$ wide, is left between them and the host cell walls. The prosorus contains a single nucleus which measures $20-37 \mu$ in diameter depending on the size of the prosorus. Rarely, however, the evanescent prosori are binucleate, indicating either that the primary nucleus has divided once, or that the original planospores which gave rise to them were themselves binucleate. The latter suggestion is made in view of the fact that abnormal planospores with more than one nucleus and binucleate threeday-old thalli have been observed (fig. 5) .

At about this stage, a dense finely granular and crescent-shaped area appears in the cytoplasm just above the nucleus (fig. 14, 15). It is similar to but more conspicuous than that described by Curtis (1921, p. 422, fig. 27-30) in S. endobioticum. This remarkable area or organoid is spherical when fully developed, lies free in the cytoplasm and does not abut on the nucleus (fig. 16). It is as large as or larger than the nucleus when fully developed. It has a circular outline in transverse sections of the prosorus and merges imperceptibly into the surrounding cytoplasm. In some preparations, especially those fixed in Carnoy's solution and stained with Newton's crystal violet, the periphery of the organoid is crowded with densely stained granules. Occasionally its center appears denser (fig. 15). In its position and gross appearance the organoid resembles a centrosome, but centrioles or astral rays are not evident. The occurrence of this unusual organoid has not been described in any
Synchytrium species. At this stage, the nucleolus is highly vacuolate, and the chromatic filaments occupy a large part of the nuclear cavity. The filaments are contorted, beaded and dispersed in a loose network of fine filaments. On the inside of the nuclear membrane 1-4 heterochromatic granules, $1.5-4 \mu$ in diam., occur (fig. 12). They become vacuolate and resemble the nucleoli in staining properties. Apparently the heterochromatic globules have been referred to as the secondary nucleoli by Kusano $(1907 \mathrm{~b}, 1930 \mathrm{~b})$ in $S$. puerariae and $S$. fulgens. The heterochromatic globules disappear along with the nucleoli during the division of the primary nucleus and do not reappear in the secondary nuclei. Apparently, they arise from the nucleoli but do not escape from the nucleus. Usually, the nuclear membrane is prominent but sometimes a part of it may be so faint in outline that the nucleoplasm appears continuous with the cytoplasm (fig. 12). The cytoplasm is alveolar, uniformly finely granular and includes coarse granules of varying sizes. The larger granules among them are vacuolate in fixed and stained sections indicating that they may have contained an oily reserve in the living condition. This is sug. gested by the fact that the granules dissected out of the living evanscent prosori became blackened when treated with osmium tetroxide fumes. Obser. vations on the changes which the cytoplasmic granules undergo from the sixth day onward indicate that they might have originated from the chromatic granules extruded from the nucleus. Because the cytoplasmic granules gradually disappear in the incipient sori, they appear to serve as reserve food globules as suggested by Kusano (1930b) for S. fulgens.

Fig. 1-57. Development and cytology of the evanescent prosori, sori and sporangia of Synchytrium brownii Karling. Fig. 1,2 and 37 , drawn from living preparations.-Fig. 1. Four planospores and a zygote (on the extreme right) adhering to the host surface. $\times 1500 .-$ Fig. 2. Infection. $\times 1500 .-$ Fig. 3. Multiple infection, one-day-old. $\times 1500 .-$ Fig. 4. Two-day-old thallus. $\times 1500$.-Fig. 5. Three-day-old thalli; one thallus is binucleate. $\times 1500 .-$ Fig. 6, 7. Four and 6-day-old thalli. $\times 1500$ and $\times 400$ respectively.-Fig. 8-12. Nucleus of 5-, 6-, 7-, 8- and 9-day-old thalli. $\times 600$, $\times 800, \times 600, \times 750$ and $\times 700$ respectively.-Fig. 13. Nine-day-old binucleate evanescent prosorus. $\times 400 .-F i g .14-16$. Nine-day-old evanescent prosori showing the gradual development of the cytoplasmic organoid and displacement of the primary nucleus to the bottom of the evanescent prosorus. $\times 350$. - Fig. 17 . Initiation of the vesicle; elongation of the primary nucleus. $\times 350$.-Fig. 18. A stage of nuclear and cytoplasmic migration to form the vesicle. $\times 350 .-F i g$. 19. A migrating nucleus. $\times 600 .-$ Fig. 20, 21. Nuclei after migration into the vesicle. $\times 350 .-$ Fig. 22. Shrunken nucleus lying near the periphery of the vesicle which is the incipient sorus. $\times 1250$. Fig. 23 . Fully formed incipient sorus. $\times 250 .-$ Fig. 24-28. Division stages of the primary nucleus,-Fig. 24. Crescent shaped primary nucleus prior to division. $\times 500 .-$ Fig. 25 . Division spindle lying in the narrow nuclear cavity. $\times 500 .-$ Fig. 26. Enlarged division spindle. $\times 1500$.-Fig. 27-28. Anaphase and telophase. $\times 500$ and $\times 250$ respectively.-Fig. 29-32. Development of the plug in the exit pore from the surrounding protoplasm. $\times 500$.-Fig. 33. Multinucleate incipient sorus; plug fully formed. $\times 330 .-F i g .34$. Early stages of division of the secondary nuclei in the incipient sorus. $\times 300 .-F i g .35$. Multinucleate incipient sorus prior to cleavage. $\times 250 .-$ Fig. 36. Progressive cleavage. $\times 250 .-$ Fig. 37 . Mature sorus with attached empty prosoral case. The sporangia are of various sizes. $\times 250 .-F i g .38$. Incipient multinucleate sporangia. $\times 250 .-F i g .39$. Incipent sporangium. $\times 1000 .-$ Fig. 40a-d. Portion of a sorus of sporangia. $\times 750 .-F i g .40 a$. Nulclei in metaphase. Fig. 40b. An undivided nucleus amidst the ultimate nuclei.-Fig. 40c. Incipient sporangium, nuclei in prophase.-Fig. 40d. Sporangium containing ultimate nuclei.-Fig. 41. Evanescent prosorus giving rise to a solosporangium. $\times 200 .-$ Fig. 42-45. Secondary nuclei after successive divisions in incipient sorus. $\times 1000 .-F i g .46-$ 49. Secondary nuclei after successive divisions in the sporangia. $\times 1000$. Fig. 50. Diagrammatic representation of the chromatic filaments in a secondary nucleus. $\times 2000 .-$ Fig. 51 . Secondary nucleus in incipient sorus. $\times 1100 .-F i g$. 52, 53. Mitotic stages in incipient sorus. $\times 1100 .-$ Fig. 51-57. Mitotic stages in incipient sporangia. $\times 1500$. 
Concomitant with the development of the cytoplasmic organoid, the nucleus is displaced toward the base of the prosorus (fig. 16). In the displaced nucleus, the untangled chromatic filaments are scattered in a loose network of fine and achromatic filaments which fill the nuclear cavity (fig. 16, 17). The primary nucleus thus appears to be in early prophase, as has been described by Curtis (1921) and Karling (1955a) for the migrating primary nucleus of $S$. endobioticum and $S$. australe respectively. Meanwhile, the peripheral protoplasm begins to differentiate almost at any point along the upper half of the evanescent prosorus. In the region of differentiation the protoplasm is free of large granules or vacuoles and a papillate outgrowth soon develops (fig. 17). As the papillum enlarges, a small vesicle is formed into which the cytoplasm gradually flows in the manner described for the development of the prosorus in S. endobioticum by Curtis (1921) and in several species by Karling (1955a, b, c, e). As the cytoplasm migrates outward the coarse granules in it decrease in size and number (fig. 18, 20). The vesicle or incipient sorus is fully formed in about $6 \mathrm{hr}$. It is somewhat reniform and lies on the top or to one side of the empty prosorus (fig. 20, 21, 27). So far the incipient sorus has not been found to develop below the evanescent prosorus as illustrated by Schroeter (1870) in S. stellariae. As the incipient sorus develops further, it invaginates and col. lapses the prosoral case and forces it to the base or to one side of the host cell (fig. $33,36,38$ ).

Concomitant with the development of the papillum and the initiation of the incipient sorus, the dense cytoplasmic organoid described previously in the evanescent prosorus becomes drawn out and comet-shaped with its "tail" directed towards the exit papillum (fig. 17). As more cytoplasm flows out, the comet-shaped organoid also moves upward so that its "tail" reaches the exit pore. Then, the displaced primary nucleus also begins to move upward and assumes the shape of a tear-drop (fig. 17). It elongates as it moves toward the exit pore, and in this shape it overlaps the comet-shaped organoid which preceded it. After this stage, the cytoplasmic organoid is no longer detectable. Figure 19 shows the elongate, migrating primary nucleus at the exit pore. Most of the filaments remain in the lower part of the migrating nucleus, whereas the homogeneous nucleolus is located near the upper narrow end. Curtis (1921), on the other hand, reported that the nucleolus in $S$. endobioticum usually remains near the posterior part of the migrating nucleus.

By the time the vesicle is about $15 \%$ in diameter the narrow end of the primary nucleus passes through the exit pore and enlarges inside the vesicle (fig. 18). The last portion of the nucleus to migrate through is narrow so that the migrated nucleus is top-shaped (fig. 20). It moves upward in a straight line, and eventually lies near the upper periphery of the incipient sorus (fig. 23). 'The migrated primary nucleus has a wavy outline, and only rarely does it assume the shape it had in the prosorus (fig. 21, 23). Kusano (1907a, 1930b) also described, in $S$. decipiens, $S$. puerariae and $S$. fulgens, conspicuous shrinkage of the primary nuclei prior to division. In $S$. brownii the shrunken primary nucleus then becomes somewhat lenticular (fig. 22). The nucleolus is homogeneous and appears to be degenerating. The reticulate chromatic filaments are no longer present as such, but groups of stout contorted rods are visible in the nuclear cavity (fig. 22). Then both ends of the nucleus elongate in opposite directions so that the nucleus becomes distinctly crescent-shaped with a narrow cavity (fig. 24, 25). Kusano also described the narrowing of the nuclear cavity prior to division in $S$. fulgens, whereas such deformation was not described for $S$. endobioticum by Curtis (1921). From this stage onward the nuclear membrane is not visible as an intact entity in S. brownii. A dense zone of fine granules and discontinuous filaments encloses the narrow nuclear cavity (fig. 24-28). A dense cytoplasmic background has been noted for the dividing primary nucleus of $S$. decipiens by Stevens and Stevens (1903) and Griggs (1909). In $S$. fulgens, the dissolution products of the nucleus were believed by Kusano (1930b) to give rise to a dense area around the dividing primary nucleus. In $S$. brownii, a well-developed spindle appears in the middle of the narrow nuclear cavity (fig. 25). Five ovoid chromosomes appear to lie across the equator of the spindle (fig. 25, 26), and the nucleolus which remains at one side of the cavity either disappears or becomes inconspicuous. At anaphase the chromosomes appear as clumps on the drawn out spindle (fig. 27). The surrounding dense zone extends far beyond the division spindle. The spindle is about $10-14 \times 4 u$ and the chromosomes are $0.6 \times 1 \mu$. At telophase the two daughter nuclei lie about $20 \%$ apart, and each measures $7 \mu$ in diameter (fig. 28). They include a few thickened bodies and a few chromatic filaments on the inside of the nuclear membrane. However, the nucleoli are not visible in these nuclei. The division of the primary nucleus as described above resembles that of $S$. fulgens, $S$. puerariae, and $S$. decipiens more than that of $S$. endobioticum. In the latter, the nuclear membrane is reported to be intact at metaphase. As the spindle appears in the nuclear cavity, the division is intranuclear in $S$. brownii also, but the nuclear meml,rane is not visible at metaphase.

The division of the primary nucleus is followed in quick succession by division of the secondary nuclei until more than 100 nuclei are formed (fig. 33-36). In the prophases of such divisions, conspicuously nodular filaments appear in the nuclei (fig. 33). At first, the chromatic filaments appear 
looped or wavy on the inside of the nuclear membrane (fig. 50). Then the nuclear membrane disappears and a well-developed spindle and 5 chromosomes appear (fig. 52-56). Tynical intra. nuclear spindles as shown by Cirtis (1921) and Rytz (1917), or conspicuous centrosomes and astral rays as described by Stevens (1907). Griggs (1908, 1909), Rytz (1917) and Kusano (1907a, b, 1908, $1930 \mathrm{~b}$ ) in other species were not observed in connection with the nuclear divisions in $S$. brownii. In other respects the divisions are similar to those described and figured by Kusano (1930b) for $S$. lulgens. After telophase the nuclei are reconstituted but the nucleoli may or may not be evident in the secondary nuclei.

Development of the plug.--Shortly after the primary nucleus has divided in the incipient sorus, the granular cytoplasm on either side of the exit pore gradually becomes homogeneous and hyaline (fig. 29, 30). At first this transformation takes place along the borders of the pore, and a bilabiate hyaline structure is formed (fig. 31). Further transformation of the cytoplasm gives rise to a hvaline and dumbell-shaped structure which completely closes the opening (fig. 32). This structure is referred to here as a plug. The formation of the plug is initiated soon after the division of the primary nucleus and is completed when the incipient sorus is multinucleate (fig. 28, 33-36). The plug takes plasma stains readily in the early stages, but at later stages it stains deeply with crystal violet or safranin. With chlor-iodide of zinc the plug stains pink. Such plugs have been illustrated in several species which produce prosori as well as in the germinating resting spores which function as prosori (Rytz. 1907; Kusano, 1930a ; Karling, 1955a, b, c. e, 1956; Lingappa, 1955a). Though the plugs have not been described by Curtis (1921) in S. endobioticum a study of that species by the author has shown that the plugs are present there also. In several other species previously studied by the author $(1953,1955 \mathrm{a}, \mathrm{b})$ they were not conspicuous. The occurrence of the plug along with a sporangiosorus is considered by Karling (1956) as an indication that the initial cell has functioned as a prosorus and is being considered as one of the diagnostic features of some Synchytrium species. In the evanescent prosori and the germinating resting spores, apparently the plug functions as a means of closing the pore so that the content of the incipient sorus does not re-enter the prosoral case when the incipient sorus expands and develops into a sorus of sporangia.

DEVELOPMENT OF THE SPORANGIOSORUS AND SPORANGIA.- The completion of nuclear divisions in the incipient sorus is followed by cleavage of the protoplasm into incipient sporangia. As has been shown in other Synchytrium species, cleavage begins at the periphery, progresses inward and eventually divides the entire content into polyhedral and multinucleate segments (fig. 36, 38). Occasionally, broad linear areas appear among the segments, but hydration of these segments follows shortly afterwards so that their outlines are temporarily indistinguishable. At maturity each segment is enveloped by a separate hyaline wall (fig. 37, $38,40)$. These multinucleate segments are the incipient sporangia. No evidence of the formation of protospores as described by Harper (1899) in S. decipiens and Karling (1955e) in S. oxalidis has been found in $S$. brownii. In the incipient sporangia the nuclei resume mitotic divisions (fig. 40). At metaphase a faintly stained and degenerating nucleolus is present near the division spindle (fig. 54, 55). Essentially, the nuclear divisions in any one sporangium of the sorus are simultaneous, although some of the division stages are slightly more advanced than others. The secondary nuclei become progressively smaller after each division so that the ultimate nuclei measure about $1.5 \mu$ in diameter and lack a distinct nucleolus. They contain 1-5 chromatic granules and beaded filaments on the inside of the nuclear membrane (fig. $40 \mathrm{c}$, 49). In rare cases a large single nucleus, $4 \mu$ in diameter, occurs among the ultimate nuclei which suggests that it did not divide along with other nuclei (fig. 40b). There is no evidence of intrasporangial fusion of the secondary nuclei as recently reported in S. endobioticum by Mme. Heim (1956). However, all Heim's original findings contradict every established fact in the development and cytology of $S$. endobioticum and other $S y n$ chytrium species, and her descriptions and figures are unconvincing. Furthermore, in experimentally degenerated incipient sori and sporangia of $S$. brownii, pycnotic nuclei simulate the conditions described by Heim. Therefore, the author believes that Heim's observations relate to artifacts, or misinterpretations, or both.

At $24^{\circ} \mathrm{C}$., about $6 \mathrm{hr}$. are needed for the content of the evanescent prosorus to flow out and develop into an incipient sorus and $8 \mathrm{hr}$. or more for the formation of sporangia. In the living condition the newly formed sporangia contain numerous large irregularly dispersed oil globules, but by the time the sporangia are mature their content appears homogeneous, finely granular and bright yellowishorange. The sporangia are formed within the wall of the vesicle which envelops them as a common membrane (fig. 37). The sorus may contain one to 200 or more (usually $40-60$ ) sporangia. The sporangia are polyhedral, but with the absorption of water they become oval, pyriform or subspheri-

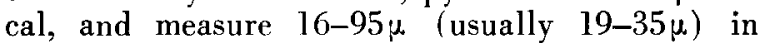
greatest diameter. Very rarely, the multinucleate content of the incipient sorus fails to undergo cleavage and a single sporangium with a wall of its own is formed (fig. 41). The evanescent prosori which give rise to such solosporangia are much smaller 
than the normal ones. Similar solosporangia have been reported for S. endobioticum by Curtis (1921) and Schilherzsky (1930).

When chlor-iodide of zinc is applied to an intact sorus with its attached evanescent prosoral case, the original prosoral wall remains hyaline while its inside (endospore ?) as well as the common soral membrane become brick red. The plug and the sporangial walls become pinkish. The occurrence of cellulose in these structures has not been demonstrated by this procedure.

All sporangia in a sorus do not mature at the same time. This was evident in the stained sections in which mitoses were present in some sporangia while in others mitoses had been completed (fig. 40). After the complete development of the sporangia, several $\mathrm{hr}$. of maturation are required before sporogenesis begins. Also, maturation does not occur in all sporangia of the same sorus at the same time. Once sporogenesis has begun, the planospores are liberated within an hr. at $20-27^{\circ} \mathrm{C}$. in abundant fresh water. The planospores are able to reinfect the host and give rise to another propagating generation of evanescent prosori, sori and sporangia. A complete developmental cycle from zoospore to zoospore is achieved within 7 days at $30^{\circ} \mathrm{C}$.

When leaves bearing ripe sori are placed in fresh water or in a humid chamber, masses of sporangia are forcibly extruded from the galls. In the natural habitat also, the ripe sporangia are scattered abundantly on the leaf surface, and in this respect $S$. brownii resembles $S$. fulgens whose sporangia were described by Schroeter (1870) as being scattered on the host surface like loose uredospores. Most of such exposed sporangia do not wet properly and fail to germinate.

At $30^{\circ} \mathrm{C}$., mature sporangia are formed from the evanescent prosori within a week after infection, but they lose viability within five days when retained at that temperature. On the other hand at $20^{\circ} \mathrm{C}$., sporangia are formed in about two weeks after infection, and viable sporangia may be obtained one month after inoculation. The sporangia produce planospores at $3-30^{\circ} \mathrm{C}$., with $20-25^{\circ} \mathrm{C}$. as an optimum. Exposure to $35^{\circ} \mathrm{C}$. for one hr. kills the sporangia. However, they can withstand freezing and thawing. A few viable sporangia were obtained from leaves bearing abundant mature sori which were stored for seven weeks at $-16^{\circ} \mathrm{C}$. A large number of viable sporangia, on the other hand, may be recovered from similar leaves which were stored for seven weeks at $5^{\circ} \mathrm{C}$. The sporangia lose viability when air dried. Their ability to withstand freezing and to produce planospores at low temperatures might explain the occurrence of this fungus in the propagative phase and the incidence of fresh infection of the host plants out-of-doors during winter months at Lafayette, Indiana, when temperatures are below $10^{\circ} \mathrm{C}$.

\section{SUMMARY}

Synchytrium brownii is a long-cycled species which produces repeating generations of evanescent prosori, sori, sporangia and planospores on Oenothera biennis, and these comprise the propagating phase of the fungus. During infection, the planospores gradually absorb their flagella and attach themselves firmly to the host surface. Then their contents enter the epidermal cell of the host leaving their membranes and oil globules on the host surface. The intracellular thalli derived from the planospores develop into evanescent prosori in about 6 days at $30^{\circ} \mathrm{C}$., 9 days at $27^{\circ} \mathrm{C}$. or after 12 days at $20^{\circ} \mathrm{C}$. A remarkable hitherto undescribed cytoplasmic organoid develops on the primary nucleus of the mature evanescent prosorus. Then, within the host cell, the cytoplasm of the evanescent prosorus flows out to form a reniform incipient sorus. In the latter, the primary nucleus becomes attenuated and outstretched into a crescentshaped densely granular zone with a narrow cavity. A well-defined spindle with five chromosomes is formed in the narrow nuclear cavity. At metaphase a distinct nuclear membrane is not visible. After several mitotic divisions, the content of the incipient sorus cleaves into multinucleate incipient sporangia. In the latter, repeated mitotic divisions give rise to numerous ultimate nuclei, each of which is later contained in a planospore. During the development of the evanescent prosori, nuclear substances appear to be extruded into the cytoplasm and develop into coarse granules. These granules, however, disappear during sorus formation and are in all likelihood food globules. Occasionally binucleate evanescent prosori occur. The evanescent prosori rarely produce solosporangia i.e., the content of a vesicle develops into a single sporangium instead of cleaving into a sorus of sporangia.

\section{Department of Botany, \\ UNIVEISITY OF Michigan, Ann Arbor, Michigan}

\section{LITERATURE CITED}

de Bary, A., and M. Woronin. 1863. Beitrag zur Kenntniss der Chytridineen. Ber. Naturf. Ges. Freiburg. 3: $22-61$.

Cook, M. T. 1945. Species of Synchytrium in Louisiana. I. Description of species found in the vicinity of Baton Rouge. Mycologia 37: 284-294.

Curtis, K. M. 1921. The life-history and cytology of Synchytrium endobioticum (Schilb.) Perc., the cause of wart disease in Potato. Phil. Trans. Roy. Soc. London B. 210 : 409-478.

Griggs, R. F. 1908. On the cytology of Synchytrium. III. The role of centrosomes in the formation of nuclear membrane. Ohio Nat. 8: 277-286.

1909. Mitosis in Synchytrium with some observations on the individuality of chromosomes. Bot. Gaz. 48: 339-358.

Harper, R. A. 1899. Cell division in sporangia and asci. Ann. Bot., Lond. 13: 467-525. 
Heıм, P. 1956. Remarques sur le dévelopment, les divisions nucléaires et le cycle évolutif du Synchytrium endobioticum (Schilb.) Perc. Rev. Mycol. 21: 93120 .

Karling, J. S. 1954a. Synchytrium brownii, a new species with sexual reproduction. Sydowia 8: 27-30.

1954b. Host range of Synchytrium aecidioides. Sydowia 8: 355-359.

1954c. The cytology of host reaction to infection by Synchytrium australe. Amer. Jour. Bot. 41: 651663.

_- 1955a. The cytology of prosoral, soral and sporangial development in Synchytrium australe. Amer. Jour. Bot. 42: 37-41.

1955b. Synchytrium ranunculi Cook. Mycologia 47: 130-139.

1955c. Prosori in Synchytrium. Bull. Torrey Bot. Club 82: 218-236.

1955d. Hosts of Synchytrium australe. Sydowia 9: $441-447$.

-_. 1955e. Additional species of Synchytrium with prosori. Bull. Torrey Bot. Club 82: 446-462.

1956. Synchytrium fulgens in relation to other species on onegraceous hosts. Amer. Jour. Bot. 43: 61-69.

KöhlER, E. 1932. Zur Biologie und cytologie von Synchytrium endobioticum (Schilb.) Perc. Phytopath. Zeitschr. 4: 43-55.

Kisavo, S. 1907a. On the cytology of Synchytrium. Zentralblatt f. Bakt. 19: 538-543.

- -.. 1907b. On the nucleus of Synchytrium purariae Miyabe. Bot. Mag., Tokyo 21: 118-121.
1908. On "Karyodermatoplast," a nuclear membrane forming body. Bot. Mag., Tokyo 22: 205-206. 1930a. The life-history and physiology of Synchytrium fulgens Schroet., with special reference to its sexuality. Jap. Jour. Bot. 5: 35-132.

1930b. Cytology of Synchytrium fulgens Schroet. Jour. Coll. Agri., Tokyo 10: 347-388.

LingaPPA, B. T. 1953. Some new species of Synchytrium from Banaras. Mycologia 45: 288-295.

1955a. Resting spore germination in Synchytrium in relation to classification. Amer. Jour. Bot. 42: 841-850.

1955b. Some new Indian species of Synchytrium. Lloydia 18: 129-142.

Rytz, W. 1907. Beiträge zur Kenntnis der Gattung Synchytrium. Zentralblatt f. Bakt. 18: 635-655; 799-825. 1917. Beiträge zur Kenntnis der Gattung Synchytrium. 1. Fortsetsung. Die cytologischen Verhaltnisse bei Synchytrium taraxaci de By. et Wor. Beih. Bot. Zentralblatt II. 34: 343-372.

Schilberzsky, K. 1930. Die Gesamtbiologie des Kartoffelkrebses. Freiburg, Munschen.

Schroeter, J. 1870. Die Pflanzenparasiten aus der Gattung Synchytrium. Beitr. Biol. Pfl. 1: 1-50.

1873. Synchytrium fulgens n. sp. in Rabenhorst, L., Fungi europ. exsicc. Cent. XVII. no. 1601-1700. Diagnosis in Hedwigia 12: 139-144.

Stevens, F. L., And A. C. Stevens. 1903. Mitosis of the primary nucleus in Synchytrium decipiens. Bot. Gaz. 35: 405-415.

Stevens, F. L. 1907. Some remarkable nuclear structures in Synchytrium. Ann. Mycol. 5: 480-484.

\section{INCORPORATION OF PHOSPHORUS-32 INTO NUCLEIC ACIDS AND PROTEINS DURING MICROGAMETOGENESIS OF TULBAGHIA ${ }^{1}$}

\section{J. Herbert Taylor}

Although Many compounds are labeled when phosphorus-32 is fed to plants as inorganic phosphate, nearly all of these except the nucleic acids and proteins are soluble in some of the common cytological fixatives. The phosphorus-containing substances that remain after fixation can be fractionated in tissue sections when one desires to study the incorporation of $\mathrm{P}^{32}$ into a single class of substances, for example deoxyribonucleic acid (DNA) or ribonucleic acid (RNA). One of the difficulties in such studies has been the lack of information on the precision with which acids and enzymes can be utilized for quantitative separation of these substances in fixed tissues. Methods worked out for

${ }^{1}$ Received for publication September 13, 1957.

This work was supported in part by grants from the Atomic Energy Commission, Contract AT (30-1) 1304 and the Higgins Research Fund, Columbia University. A part of the chromatographic analysis was carried out while the author worked as research collaborator in the Biology Department, Brookhaven National Laboratory. The tech nical assistance of Mrs. Toni Simon is gratefully acknowledged. tissue homogenates are sometimes applicable but a lack of knowledge of how well the methods separate RNA and DNA after cytological fixation has been a major handicap (Taylor and McMaster, 1954; Moses and Taylor, 1955).

In this study $\mathrm{P}^{32}$ was supplied to anthers and incorporation allowed to continue for a brief period during the cell division cycle. Incorporation of the $\mathrm{P}^{32}$ into DNA and RNA is taken as a measure of the synthesis of the two types of nucleic acids during the various portions of the cell division cycle. This assumption appears justified since incorporation of $\mathrm{P}^{32}$ into DNA is restricted to relatively short periods of the cell cycle which have been shown to coincide with increases in the net amount of DNA per nucleus in every instance studied at the cellular level (Taylor and McMaster, 1954; Moses and Taylor, 1955). Hershey (1954) showed that $\mathrm{P}^{32}$ once incorporated into either RNA or DNA of E. coli was not renewed during subsequent cell divisions. Recently Siminovitch and Graham (1956) repeated the experiments with 